\title{
Maxillofacial tumors and tumor-like lesions : a retrospective analysis
}

\author{
Islam M A ${ }^{1}$, Hossain M A², Rahman S B ${ }^{3}$, Kawser M A4, Rahman M S5
}

Received: 04.02.18

Accepted: 25.03 .18

\section{Abstract:}

Background: This paper reviews the types, prevalence and demographic distribution of maxillofacial tumors, cysts and tumor-like lesions in a Bangladeshiteaching Hospital.An observational descriptive study (January' 2014 to December' 2016) was performed at Oral and Maxillofacial Surgery department, Dental Unit, TMSS Medical College and Hospital. This study presents 55 cases of maxillofacial tumour \& tumour like lesions collected over 3 years at a tertiary oral care centre in Bogra, Bangladesh.Objectives:To find out the distribution \& pattern of maxillofacial tumours and to find out the age, sex, site, clinical presentation and thehistological types of these tumors Method: A cross sectional descriptive study where the Histopathological types of the maxillofacial tumours were analyzed to indicate the numbers that occurred and also the pattern of occurrence according to age, gender, site and clinical presentation. Result: There were 55 maxillofacial tumour \& tumour like lesions of which 44 (80.01\%) were Benign tumours \& 11 (19.81\%) were malignant tumours. Among Eighteen histopathologic types were found of which Squamous cell carcinoma (18.18\%), Ameloblastoma (16.36\%), Odontogenic keratocystic tumour (10.90\%), Dentigerous cyst (7.27\%)\& Radicular cyst $(7.27 \%)$ were predominant. The male to female ratio was 1.29:1. Patients were between 10 years and 72 years with most patients (27.27\%) in 51 to 60 years of life. Case presented with symptoms such as swelling (41.96\%), pain (28.82\%) and loosetooth (17.12\%). Conclusion: Both malignant and benign tumours are seen. In the present study, SCC and ameloblastoma were the commonest malignant and benign odontogenic tumours seen respectively; the two representing more than $34.54 \%$ of all tumors. Tumour \& tumour like lesions of the oral \& maxillofacial region with late presentation still remains the main challenging factor in the early detection \& management. Surgery was the main modality used for treatment while some patients had no treatment due to self discharge and late presentation.

Keywords: Tumors, Odontogenic tumors, Maxillofacial, Bangladesh

1. Dr. Md. Amirul Islam, BDS,FCPS, Associate Professor\& Head, Dept. Of Oral \& Maxillofacial Surgery, TMSS Medical College Dental Unit, Bogra

2. Dr. M. Ahmed Hossain, BDS, FCPS, Assistant Professor, Dept. Of Oral \& Maxillofacial Surgery, Holy Family Red Crescent Medical College, Dhaka.

3. Dr. Sabrina Binte Rahman, BDS, FCPS, Assistant Professor, Dept. Of Oral \& Maxillofacial Surgery, Dhaka Dental College, Dhaka.

4. Dr. Md. Ali Kawser, BDS,MS, AssistantProfessor\& Head, Dept. Of Orthodontics, TMSS Medical College Dental Unit, Bogra

5. Dr. Md. Shamsur Rahman, BDS, FCPS, Associate Professor, Dept. Of Oral \& Maxillofacial Surgery, Sylhet MAG Osmani Medical College, Sylhet.

Correspondence : Dr. Md. Amirul Islam, Email: amirshaheenbd@yahoo.com, Contact: 01714219496 


\section{Introduction:}

The maxillofacial region including the jaw bones, tongue, cheek, floor of the mouth, palate \& major salivary glands region especially parotid region \& related tissues can be the site of multitude of neoplastic conditions.Mostly, the maxilla and the mandible are the sites of many cystic and neoplastic conditions which could be either benign or malignant. ${ }^{1}$ The malignant lesions usually found in the lower face include sarcomas of soft and hard connective tissue, carcinomas of the salivary glands, with SCC accounting for more than $90 \%$ of reported malignant tumors of the oral cavity and rarely melanomas. ${ }^{3,4}$ Some of these cancers however are metastases from distant sites such as the breast, lungs, abdominal organs or even the prostate gland. ${ }^{5}$ Benign lesions found in the lower face are odontogenic or non-odon-togenic tumors, predominantly ameloblastoma. ${ }^{6}$ Swellings in the orofacial region are unique due to the obvious cosmetic defect and functional impairment of the anatomically related aero-digestive tract. Orofacial tumors are known to exhibit geographic variations in prevalence and pattern due to cultural, social, occupational or climatic factors as shown by studies from Nigeria ${ }^{2,10}$, other African countries ${ }^{11,12}$, Asia ${ }^{13}$ and Western nations. ${ }^{14,15}$ Wakiaga et al.16 in a report from Kenya found ameloblastoma,Burkitt's lymphoma, ossifying fibroma and osteogenic sarcoma as the most common tumors in that order.

The orofacial region is made up of the facial skeleton supported by the covering soft tissue and encloses the oral cavity. The paired submandibular and sub-lingual salivary glands, the minor salivary glands of the lower lip, muscles and structures of the floor of the mouth are included in this region. Inferiorly, the mandible forms a boundary for the anterior triangle of the neck, which is only separated from the posterior triangle by the sternocleidomastoid muscle. ${ }^{7}$ These tri-angles contain lymph nodes into which malignant tumors spread primarily from the head and neck region and form channels through which malignancies also spread from lower parts of the body. ${ }^{7}$ Management of these tumors presents a challenge due to their sizes at presentation in the South Asian region, access for resection as well as reconstruction of both the soft tissue and bone.

The aim of this study was to determine the types, prevalence and demographic distribution of maxillofacial tumors and tumor-like lesions in a tertiary health teaching Hospital located at Bogra in Bangladeshand to compare these data with previous reports.

\section{Materials \& Methods:}

A retrospective analysis of the medical records and histological reports of patients with oral and maxillofacial tumors, cysts and tumor-like lesions who presented to Oral and Maxillofacial Surgery department, Dental Unit, TMSS Medical College and Hospital from January' 2014 to December' 2016, a period of 3 years, was undertaken. Information on demographics, histological diagnosis and clinical presentation were obtained. The 2005 WHO criteria ${ }^{18}$ were adopted for the classification of odontogenic tumors and cyst of the jaws. The age limit for categorizations of tumor occurrence into pediatric or adult type was 19 years which is similar to that adopted by Aregbesola et al. ${ }^{10}$

\section{Results:}

Table: 1 Age Distribution of Oral \& Maxillofacial tumors \& tumor like lesions

\begin{tabular}{|c|c|c|c|c|c|c|c|c|}
\hline \multirow[t]{2}{*}{ Histological types } & \multicolumn{6}{|c|}{ Age in Years } & \multirow{2}{*}{$\begin{array}{l}\text { Freque } \\
\text { ncy }\end{array}$} & \multirow{2}{*}{$\begin{array}{l}\text { Perce } \\
\text { nt }\end{array}$} \\
\hline & $1-10$ & $\begin{array}{l}11- \\
20\end{array}$ & $\begin{array}{l}21- \\
30\end{array}$ & $\begin{array}{l}31- \\
40\end{array}$ & $41-50$ & $51-60$ & & \\
\hline \multicolumn{9}{|l|}{ Odontogenic Tumour } \\
\hline Ameloblastoma & 1 & 1 & 2 & 2 & 1 & 2 & 9 & 16.36 \\
\hline $\begin{array}{l}\text { Odontogenic } \\
\text { keratocystic tumour }\end{array}$ & & 1 & 3 & 1 & 1 & & 6 & 10.90 \\
\hline CEOT & & & & & 1 & & 1 & 1.81 \\
\hline \multicolumn{9}{|c|}{ Non-Odontogenic tumour } \\
\hline Giant cell granuloma & & & & 1 & 1 & & 2 & 3.64 \\
\hline Haemangioma & & 1 & 1 & & 1 & 1 & 4 & 7.27 \\
\hline Fibroepithelial polyp & 1 & & & & & 1 & 2 & 3.64 \\
\hline Ossifying fibroma & & & 1 & & & & 1 & 1.81 \\
\hline $\begin{array}{l}\text { Langerhans cell } \\
\text { Histocytosis }\end{array}$ & & & 1 & & & & 1 & 1.81 \\
\hline Squamous papilloma & & & 1 & & & 2 & 3 & 5.45 \\
\hline $\begin{array}{l}\text { Psedocarcinomatous } \\
\text { hyperplasia }\end{array}$ & & & & & & 1 & 1 & 1.81 \\
\hline Fibroma & & & & & 2 & 1 & 3 & 5.45 \\
\hline \multicolumn{9}{|l|}{ Cysts } \\
\hline Dentigerous cysts & & 2 & 1 & & 1 & & 4 & 7.27 \\
\hline Radicular cysts & & & 1 & 2 & 1 & & 4 & 7.27 \\
\hline Dermoid cyst & & 1 & & & & & 1 & 1.81 \\
\hline Pleomorphic Adenoma & & & 1 & & & & 1 & 1.81 \\
\hline \multicolumn{9}{|l|}{ Mailgnant Tumour } \\
\hline $\begin{array}{l}\text { Squamous cell } \\
\text { carcinoma }\end{array}$ & & & 1 & 2 & 1 & 6 & 10 & 18.18 \\
\hline $\begin{array}{l}\text { Mucoepidermoid } \\
\text { carcinoma }\end{array}$ & & & & & & 1 & 1 & 1.81 \\
\hline \multicolumn{9}{|l|}{ Infectious Lesion } \\
\hline Tuberculous Lesion & & & & 1 & & & 1 & 1.81 \\
\hline Total & 2 & 6 & 13 & 9 & 10 & 15 & 55 & 100 \\
\hline
\end{tabular}


Table: 2 Distribution of the respondents by sex

\begin{tabular}{|l|l|l|l|}
\hline Histopathological diagnosis & Male $(\mathrm{n} \%)$ & $\begin{array}{l}\text { Female } \\
(\mathrm{n} \%)\end{array}$ & Total (n\%) \\
\hline Ameloblastoma & $9(16.36)$ & & $9(16.36)$ \\
\hline Odontogenickeratocystic tumour & $6(10.90)$ & & $6(10.90)$ \\
\hline CEOT & & $1(1.81)$ & $1(1.81)$ \\
\hline Giant cell granuloma & & $2(3.64)$ & $2(3.64)$ \\
\hline Haemangioma & $2(3.64)$ & $2(3.64)$ & $4(7.27)$ \\
\hline Fibroepithelial polyp & $2(3.64)$ & & $2(3.64)$ \\
\hline Ossifying fibroma & & $1(1.81)$ & $1(1.81)$ \\
\hline Langerhans cell Histocytosis & $1(1.81)$ & & $1(1.81)$ \\
\hline Squamous papilloma & $2(3.64)$ & $1(1.81)$ & $3(5.45)$ \\
\hline Psedocarcinomatous hyperplasia & & $1(1.81)$ & $1(1.81)$ \\
\hline Fibroma & $1(1.81)$ & $2(3.64)$ & $3(5.45)$ \\
\hline Dentigerous cysts & $4(7.27)$ & & $4(7.27)$ \\
\hline Radicular cysts & $1(1.81)$ & $3(5.45)$ & $4(7.27)$ \\
\hline Dermoid cyst & & $1(1.81)$ & $1(1.81)$ \\
\hline Pleomorphic Adenoma & & $1(1.81)$ & $1(1.81)$ \\
\hline Squamous cell carcinoma & $3(5.45)$ & $7(12.73)$ & $10(18.18)$ \\
\hline Mucoepidermoidcarcinoma & $1(1.81)$ & & $1(1.81)$ \\
\hline Tuberculous Lesion & & $1(1.81)$ & $1(1.81)$ \\
\hline Total & $\mathbf{3 1 ( 5 6 . 3 6 )}$ & $\mathbf{2 4 ( 4 3 . 1 6 )}$ & $\mathbf{5 5 ( 1 0 0 )}$ \\
\hline
\end{tabular}

Among the 55 respondents 31 (56.36) were male and rest $24(43.16)$ were female.

Table: 3Distribution of the Lesion in Maxillofacial region

\begin{tabular}{|l|l|l|l|l|l|l|l|}
\hline Histopathological diagnosis & $\begin{array}{l}\text { Mandibl } \\
\text { e }\end{array}$ & Maxilla & $\begin{array}{l}\text { Buccal } \\
\text { mucosa }\end{array}$ & Sinus & Lip & Parotid & Tongue \\
\hline Ameloblastoma & 9 & & & & & & \\
\hline $\begin{array}{l}\text { Odontogenickeratocystic } \\
\text { tumour }\end{array}$ & 4 & 2 & & & & & \\
\hline CEOT & 1 & & & & & & \\
\hline Giant cell granuloma & 1 & 1 & & & & & \\
\hline Haemangioma & & & & & 3 & & 1 \\
\hline Fibroepithelial polyp & & 1 & 1 & & & & \\
\hline Ossifying fibroma & 1 & & & & & & \\
\hline Langerhans cell Histocytosis & 1 & 1 & & & & & \\
\hline Squamous papilloma & & & 3 & & 1 & & \\
\hline $\begin{array}{l}\text { Psedocarcinomatous } \\
\text { hyperplasia }\end{array}$ & & & 1 & & & & \\
\hline Fibroma & 1 & 1 & 1 & & & & \\
\hline Dentigerous cysts & 1 & 2 & & 1 & & & \\
\hline Radicular cysts & 3 & 1 & & & & & \\
\hline Dermoid cyst & & & & & 1 & & \\
\hline Pleomorphic Adenoma & & 1 & & & & & \\
\hline Squamous cell carcinoma & 4 & 3 & 5 & 1 & & & \\
\hline Mucoepidermoidcarcinoma & & & & & & 1 & \\
\hline Tuberculous Lesion & & & 1 & & & & \\
\hline Total (60) & $\%(43.33$ & $13(21.66)$ & $12(20 \%)$ & $2(3.33$ & $5(8.3$ & $1(1.66 \%)$ & $1(1.66 \%)$ \\
\hline
\end{tabular}

Table: 4 Distribution of the lesion by Histopathological findings and Clinical features

\begin{tabular}{|c|c|c|c|c|c|c|c|c|}
\hline $\begin{array}{l}\text { Histopathological } \\
\text { diagnosis }\end{array}$ & \begin{tabular}{|l|} 
Swellin \\
$\mathrm{g}$
\end{tabular} & Pain & $\begin{array}{l}\text { Ulceratio } \\
\text { n }\end{array}$ & \begin{tabular}{|l|}
$\begin{array}{l}\text { Loose } \\
\text { tooth }\end{array}$ \\
\end{tabular} & Paresthesia & $\begin{array}{l}\text { Displaced } \\
\text { tooth }\end{array}$ & $\begin{array}{l}\text { Missing } \\
\text { Tooth }\end{array}$ & $\begin{array}{l}\text { Dischargi } \\
\text { ng Sinus }\end{array}$ \\
\hline Ameloblastoma & 8 & 5 & & 5 & 1 & 1 & 1 & \\
\hline $\begin{array}{l}\text { Odontogenic } \\
\text { keratocystic } \\
\text { tumour }\end{array}$ & 6 & 4 & & 1 & & 2 & & \\
\hline CEOT & 1 & 1 & & 1 & & 1 & & \\
\hline $\begin{array}{l}\text { Grant cell } \\
\text { granuloma }\end{array}$ & 2 & 2 & & 2 & & & & \\
\hline Haemangioma & 4 & & & & & & & \\
\hline $\begin{array}{l}\text { Fibroepithelial } \\
\text { polyp }\end{array}$ & 2 & & & & & & & \\
\hline Ossifying fibroma & 1 & & & 1 & & 1 & & \\
\hline $\begin{array}{l}\text { Langerhans cell } \\
\text { Histocytosis }\end{array}$ & & 1 & & 1 & & & & \\
\hline $\begin{array}{l}\text { Squamous } \\
\text { papilloma }\end{array}$ & 3 & 1 & & & & & & \\
\hline $\begin{array}{l}\text { Psedocarcinomato } \\
\text { us hyperplasia }\end{array}$ & 1 & & & 1 & & & & \\
\hline Fibroma & 3 & & & & & & & \\
\hline Dentigerous cysts & 4 & 3 & & 2 & & & 2 & 1 \\
\hline Radicular cysts & 3 & 2 & & 1 & & & & \\
\hline Dermoid cyst & 1 & & & & & & & \\
\hline $\begin{array}{l}\text { Pleomorphic } \\
\text { Adenoma }\end{array}$ & $\begin{array}{lll}1 & & \\
\end{array}$ & 1 & & & & & & \\
\hline $\begin{array}{l}\text { Squamous cell } \\
\text { carcinoma }\end{array}$ & 6 & 10 & 3 & 4 & 1 & & & \\
\hline $\begin{array}{l}\text { Mucoepidermoid } \\
\text { carcinoma }\end{array}$ & 1 & 1 & & & & & & \\
\hline $\begin{array}{l}\text { Tuberculous } \\
\text { Lesion }\end{array}$ & & 1 & & & 1 & & & \\
\hline \begin{tabular}{|l} 
Total(112) \\
\end{tabular} & $\begin{array}{l}47(41.9 \\
6 \%)\end{array}$ & \begin{tabular}{|l|}
$32(2$ \\
8.82 \\
$\%)$
\end{tabular} & $3(2.70 \%)$ & $\begin{array}{l}19(17 . \\
12 \%)\end{array}$ & $2(1.80 \%)$ & $5(4.50 \%)$ & $\begin{array}{l}3(2.70 \\
\%)\end{array}$ & $1(0.90 \%$ \\
\hline
\end{tabular}

\section{Discussion:}

Tumors and tumor like lesions affecting the oro-facial region are fairly common in the South Asian region. Studies, ${ }^{8,9}$ have also shown that these lesions are common in both adults and children and are more common in the mandible. Furthermore, benign as well as malignant lesions are found in the oro facial region.

Frequencies of Odontogenic tumour vary, partly because of differences in the parameters used by the authors. Some authors consider these tumors to be infrequent in children and adolescents, but base their estimate on the full range of diseases known to affect this population, or on oral and facial tumors and tumor-like lesions ${ }^{17,18,19,20}$. Adebayo et al ${ }^{21}$ attribute the high percentage of OT they observed in patients aged up to 18 years, and which accounted for $31 \%$ of buccomaxillary tumors and tumor like lesions, to the ethnic characteristics of the study population. However, Sato et $\mathrm{al}^{22}$ and Tanaka et al ${ }^{39}$ observed a similar frequency in their respective series of Japanese patients when applying the same criteria to analyze their results. In this study we observed 16 cases of Odontogenic tumour accounts $29.07 \%$ of all Maxillofacial tumour \& tumour like lesions \& mostly were cases $9(16.36 \%)$ of Ameloblastoma.

Several studies showed that Ameloblastoma occurs 
with equal frequency in men and women ${ }^{23,24,25}$. However Podtarand Farzad showed a male preponderance as male / female ratio 1.7:1.27Ahmed $M$ found that it is prevalent between 2 nd to 4th decades of life but Haider IA ${ }^{26}$ found that age distribution may vary widely from first to fifth decade of life and most commonly found in 21-30 years of age. Sadat, Ahmed M et al ${ }^{27}$ found that the age ranged from 19 years to 58 year, and peak age was in the 2nd and 3rd decades.Molla MR et al ${ }^{28}$ and Onguti MN et a ${ }^{29}$ mentioned that about $80 \%$ of the tumours in the mandible. The molar and ramus area in the most frequently involved ${ }^{30}$. Haider $I^{26}$ reported that most common sites of Ameloblastoma in mandible, (94.28\%) involved the molar region. Mehlisch et al31 reported that the presenting clinical signs and symptoms of the Ameloblastoma vary from patient to patient. The most common symptoms were swelling which occurred in $75 \%$ of the patients, followed by pain and swelling which was about $33 \%$. Sadat,Ahmed $M$ et al (2005)20found swelling is the most common presenting feature $50 \%$ of Ameloblastoma, where swelling and pain are $29.16 \%$. In this study, we found $9(16.36 \%)$ cases of Ameloblastomaoccurred 1st decade to 6 th decades, all occurred in mandible \& all were male presented with mostly swelling associated with pain \& loose teeth.

In recent $\mathrm{WHO}$ criteria ${ }^{21}$ odontogenic keratocysts categorized as odontogenic tumor (Keratocystic odontogenic tumor (KCOT) was the next most common lesion (8.2\%) after ameloblastoma across the series. This is contrary to the findings in some studies where KCOT were reported as the most prevalent OT in studies that used the 2005 WHO classification. ${ }^{32,33}$ Expectedly, inclusion of this cystic lesion as OT slightly $(8.2 \%)$ increased the overall proportion of OT in the series but it was much lower than the almost $50.0 \%$ increment observed by Servato et al. in a recent Brazilian study..$^{33}$ In our study we observed 6 (10.90\%) cases of Odontogenic keratocystic tumour, all were male \& predominantly at mandible.

Jones et al ${ }^{17}$ found odontoma accounts for $73 \%$. Conversely, Adebayo et al ${ }^{21}$ and Ajayi et al 34 found odontoma to account for $7.7 \%$ and $4.3 \%$ of OT res-pectively. This marked difference could be attributed to the fact that this lesion is usually asymptomatic and therefore remains undetected. There are no cases of odontoma reported in the present work. The series evaluated by Asamoa et $\mathrm{al}^{35}$ in which adenomatoid odontogenic tumor were the most frequent. However, it must be pointed out that according to the latter authors adenomatoid odontogenic tumor is the most frequent true odontogenic neoplasm, and ameloblastoma is the second most frequent.

Jaw cyst is described as a pathological cavity that contains fluid, semi-fluid, or gaseous substance. Its frequency has been reported from $7.8 \%$ to $36 \%$ of jawbone biopsies ${ }^{46}$. Radicular cyst, dentigerous cyst, and odontogenic keratocyst (OKC) are the three most common cysts in jawbones. ${ }^{47}$ In this study, the most common cystic lesions were radicular cyst and dentigerous cyst (14.54\%) that is consistent with results of other studies, ${ }^{48,49}$ However, Rezvani et al reported oral cysticlesions in decreasing frequency as radicular cyst(32.83\%), dentigerous cyst (31.34\%), and OKC $(26.12 \%) .{ }^{50}$ The study by Baghaei et al showed prevalence of dentigerous cysts $27.2 \%$, radicular cysts $18.6 \%$ and OKC $18.6 \% .{ }^{51}$ This variation indicates that the racial and environmental factors probably influence on development of these lesions.Radicular cysts were more common among patients in the third and fourth decade of life. This finding is consistent with a study in Italy. ${ }^{47}$ Arotiba et al indicated that mean age of occurrence was 26.5 years for radicular cyst. ${ }^{52}$ In a study by Meningaud et al, patients with radicular cyst were $38.4 \pm 17.9$ years. ${ }^{53}$ Nevertheless, Fomete et al reported second decade as peak age for radicular cysts among Nigerian patients..$^{54}$ Radicular cysts occurred most frequently in the anterior part of the maxilla (45\%) as reported previously by Tortorici et al ${ }^{47}$ Ramachandra et al ${ }^{48}$ and Koseoglu et al ${ }^{49}$.

Haemangiomas are benign vascular tumours common in childhood. Tanaka et al. ${ }^{32}$ in 1999 , assessed the maxillofacial tumours of 105 patients younger than 15 years. They found 25 oral haemangiomas $(36.2 \%)$, being the most common tumour in children. Corrêa et al. ${ }^{57}$ in 2005 , studied the prevalence of oral haemangiomas in a Brazilian population; out of 2419 lesions, 22 cases were oral haemangioma $(0.9 \%)$, mostly in the adult population. Most haemangiomas are diagnosed at an early age ${ }^{55}$. In this study we present 4 cases of oral haemangiomas were diagnosed 3 were on lip \& one at tongue with equal sex predilection though the literature ${ }^{56}$ shows a higher incidence in girls. 
Fibro-osseous lesions occurred over the second to the sixth decade with peak age of second and third decade for fibrous dysplasia and ossifying fibroma respectively. The often observed female predominance ${ }^{29,30}$ and predilection for the maxilla ${ }^{29,30}$ reported in the literature.Ossifying fibroma detected prevalently localized in the mandible has been described by Lerda et al. ${ }^{44}$ It has also been detected in the maxilla, paranasal sinuses and peripheral bones. Its growth is, however, very slow and it is usually asymptomatic, and for the later reason, it often reaches a considerable size. In the present study we found only one case of Ossifying fibroma at mandible of a 2 nd decade female patient.

Malignant lesions usually found in the oro-facial region squamous cell carcinoma, carcinomas of the salivary glands, with SCC accounting for more than $90 \%$ of reported malignant tumors of the oral cavity, and also melanomas and those that metastasize from distant sites such as the breast, lungs, abdominal organs or even the prostate gland. ${ }^{3,40}$ Malignant tumors of the jaws are grouped into central and secondary lesions. $^{13}$ Central as originating within the jaw boneand secondary, predominantly oral cancers and meta-static lesions that involve the bone secondarily.The observed SCC prevalence of $18.18 \%$ is lower to the $73.1 \%$ found in Zimbabwe ${ }^{41}$ and much lower than $90 \%$ prevalence reported by Sapp ${ }^{3}$ and Neville. ${ }^{4}$ SCC was formerly thought to be a tumor with a common presentation in the older age group. However, recent studies report the increasing occurrence of this tumor in the younger age group. ${ }^{42}$ In this study we found $10(18.18 \%)$ cases of Squamous cell carcinoma among all maxillofacial tumours mostly occurred on buccal mucosa in between 2nd to 6th decades of life presented with ulceration \& loose tooth.

Primary central mucoepidermoid carcinoma of the jaws is a rare lesion ${ }^{43}$ often manifesting as a low grade lesion composed of well differentiated mucous and epidermoid cells forming cystic spaces, but invading adjacent tissues without encapsulation. It is usually associated with salivary glands and account for $5-10 \%$ of all salivary gland tumours. ${ }^{43}$ In this study we found only one case of mucoepidemoid carcinoma of parotid gland of a 6th decade patient. Generally, studies from the developed countries reports higher proportion of malignant jaw lesions than benign lesions when compared to reports from Africa. This observed difference may be explained in terms of relatively lower life expectancy among Africans compared to their Western counterparts. ${ }^{31}$ In this study we observed less frequent maxillofacial tumours were Pseudocarcinomatous hyperplasia, Langerhans cells Histocytosis, Dermoid cysts, Calcifying epithelial odontogenic tumour, Fibroma \& a extra-pulmonary tubeculous lesion.

\section{Conclusion:}

The epidemiology of oral and maxillofacial tumors observed in this study is similar to previous reports from this part of the globe. Our observed age of occurrence variedfrom previous reports from Bangladesh. Late presentation still remains the main challenging factor in the early detection and management of maxillofacial tumors. More awareness campaign is necessary, especially at the primary health care level, to educate the populace on the need for early presentation at treatment centers.

\section{References:}

1. Keszler A, Guglielmotti MB, Dominguez FV. Oral pathology in children. Frequency, distribution and clinical significance. Acta Odont Latinoamer 1990;5:39-48.

2. Arotiba JT, Adebola RA, Ajike SO, Adeola DS, La $\neg$ deinde A. Orofacial tumors and tumor-like lesions in Kano, Nigeria. Nig J Surg Research 2003; 5:134-139

3. Neville BW, Damm DD, Allen CM, Bouquot JE. Oral and Maxillofacial Pathology. 2. Philadelphia, WB Saunders Co; 2002. 356, 376-80, 420-430, 480-90, 517-24, 574-80, 5823.

4. Daley T, Darling M. Nonsquamous cell malignant tumours of the Oral Cavity: An Overview. Can Dent Assoc. 2003; 69: 577-582.

5. Arotiba GT, Ladeinde AL, Arotiba JT, Ajike SO, Ugboko VI, Ajayi OF. Ameloblastoma in Nigerian children and adolescents: a review of 79 cases. J Oral and Maxillofac Surg. 2005; 63: 747-751.

6. Watkinson JC, Gaze MN, Wilson JA. Stell and Maran's Head and Neck Surgery. 4. Butterworth - Heineman; 2000: pp. 197-232.

7. Ajayi OF, Ladeinde AL, Adeyemo WL, Ogunlewe MO. Odontogenic tumors in Nigerian children and adoles-cents - a retrospective study of 92 cases. World J Surg Oncol. 2004; 2: 39-48.

8. Adebayo ET, Ajike SO, Adekeye EO. Tumours and tumour - like lesions of the oral and perioral structures of Nigerian children. Int J Oral Maxillofac Surg. 2001; 30: 205-208.

9. Al - Khateeb T, Hamasha AA, Almasri NM. Oral and Maxillofacial tumours in North Jordanian children and 
adolescent: a retrospective analysis over 10 years. Int $\mathrm{J}$ Oral Maxillofac Surg. 2003; 32: 78-83.

10. Aregbesola SB, Ugboko VI, Akinwande JA, Arole GF, Fagade OO. Orofacial tumors in suburban Nige-rian children and adolescents. Br J Oral Maxillofac Surg 2005; 43: $226-231$

11. Mohamed A, Singh AS, Raubenheimer EJ, Bouck $\neg$ aert MMR . Adenomatoid odontogenic tumor: review of the literature and an analysis of 33 cases from SouthAfrica. Int J Oral Maxillofac Surg 2010; 39: 843-846

12. Abdulai AE, Nwamah IK, Gyasi R. Head and Neck tumors in Ghanaian children. A 20 year review. Int J Oral Maxillofac Surg 2012; 41:1378-1382

13. Sankaranarayan R . Oral cancer in India:an epidemio $\neg-$ logical and clinical review. Oral Surg Oral Med Oral Pathol 1990; 69:325-330

14. Binnie WH. A perspective of oral cancer. Proc R Soc Med 1976; 69:737-740

15. Krutchkoff DJ, Chen J, Eissenberg E, Katz RV. Oral cancer: a survey of 566 cases from the University of Connecticut oral pathology biopsy service 1975-1986. Oral Surg Oral Med Oral Pathol 1990; 70:192-198

16. Wakiaga JM, Oyango JF, Awange DO. Clinico-path $\neg 0-$ logical analysis of jaw tumors and tumor-like condi-tions at the Kenyanta National Hospital. East Afr Med J 1997; 74(2): 65-68

17. Jones AV, Franklin CD. An analysis of oral and maxillofacial patho-logy found in children over a 30-year period. Int J Paediatr Dent 2006; 16:19-30.

18. Ulmansky M, Lustmann J, Balkin N. Tumors and tumors like lesions of the oral cavity and related structures in Israeli children. Int J Oral Maxillofac Surg 1999;28:291-4.

19. Chen Y-K, Lin L-M, Huang H-C, Lin C-C, Yan Y-H. A retrospective study of oral and maxillofacial biopsy lesions in a pediatric population from southern Taiwan. Pediatr Dent 1998;20:404-10.

20. Lawoyin JO. Paediatric oral surgical pathology service in an African population group: 10 year review. Odontostomatol Trop 2000;23:27-30.

21. Adebayo ET, Ajike SO, Adeyeke EO. Odontogenic tumors in children and adolescents: a study of 78 Nigerian cases. J CranioMaxillofac Surg 2002;30:267-72.

22. Sato M, Tanaka N, Sato T, Amagasa T. Oral and maxillofacial tumours in children: a review. $\mathrm{Br} \mathrm{J}$ Oral Maxillofac Surg 1997;35:92-5.

23. Small LA, Waldron CA, 1955.Ameloblastoma of the jaws .Oral Surgery Oral Medicine Oral Pathology1995: 8; 281-7

24. Robinson HBG. Ameloblastoma; a survey of three hundred and seventy nine cases from the literature. Archive Pathology1937: 23; 831-843.

25. Daramola JO, Ajagbe HA, Oluwasanmi JO. Ameloblastoma of the jaws in Nigerian children: a review of 16 cases. Oral Surgery 1975: 40;458-463.

26. Haider IA. Histological types of Ameloblastoma and their relationship with radiological findings. Thesis (MS) 2004.Dhaka Dental College and Hospital.
27. Sadat SMA, Ahmed M, Hossain KA, Bhuiyan RA, Rita SN. Ameloblastoma of Jaws: A Clinico pathological Study of 24 cases. The Journal of Bangladesh Orthopedic Society2005: 20; 29-33.

28. Molla MR, Shaheed I, Shrestha. Ameloblastoma-A clinical study of 13 cases. Bangladesh Medical Research Council Bulletin1991: 17(1);29-36.

29. Onguti MN, Cruchley AT, Howells GL, Williams DM. Ki67 antigen in ameloblastomas: correlation with clinical and histological parameters in 64 cases from Kenya. International Journal Oral Maxillofacial Surgery 1997:26;376-379.

30. Tahoma $\mathrm{KH}$. The pathogenesis of the odontogenic tumours. Oral Surgery1961:4; 1262.

31. Mehlisch DR, Dahlin DC, Mason JK. Ameloblastoma of jaws in Nigerian children: review of 16 cases. Oral Surgery1972: 30; 9-22.

32. Tawfik MA, Zyadia MM. Odontogenic tumors in Dakahlia, Egypt: analysis of 82 cases. Oral Surg Oral Med Oral Pathol Oral radiol Endod 2010; 109: 67-73

33. Avelar RI, Antunes AA, Santos T, de S, Andrade ES et al. Odontogenic tumors: clinical and pathology study of 238 cases. Braz J Otorhinolaryngol 2008; 74:668-673

34. Ajayi OF, Ladeinde AL, Adeyemo WL, Ogunlewe MO. Odontogenic tumors in Nigerian children and adolescents a retrospective study of 92 cases.World J Surg Oncol 2004;2:39.

35. Asamoa EO, Ayanlere AO, Olaitan AA, Adekeye EO. Paediatric tumours of the jaws in Northen Nigeria. J CranioMaxillofac Surg 1990; 18:130-5.

36. Williams AO, Browne PM, Akinosi JO. Fibro-osseus lesions of the jaws in Nigeria. J Natl Med Assoc 1974; 66:185-191

37. Waldron CA, Giansanti JS. Benign fibro-osseus le $\neg$ sions of the jaws: a clinic-radiologic histologic review of 66 cases. Oral Surg 1973; 35:190-201

38. Adekeye EO, Asamoa E, Cohen B. Intraoral carncinoma in Nigeria: a review of 137 cases. Ann R Coll Surg Engl $1985 ; 6: 181-182$

39. Tanaka N, Murata A, Yamaguchi A, Kohama G. Clinical features and management of oral maxillofacial tumors in children. Oral Surg Oral med Oral Pathol Oral Radiol Endod 1999;88:11-5.

40. Weber AL, Bui C, Kaneda T. Malignant tumors of the mandible and maxilla. Neuroimaging Clin N Am. 2003; 13: 509-524. doi:10.1016/S1052-5149(03)00042-X.

41. Cancer Research Campaign Factsheet. 1990: pp. 14.1-14.5.

42. Lund VJ. Malignancy of the nose and sinuses: epidemiological and aetiological considerations. Rhinolo- gy. 1991; 29: 57-68.

43. Eversole LR. Mucoepidermoid carcinoma: Review of 815 reported cases. Oral Surg Oral Med Oral Path. 1970; 28: 490-495.

44. Anil S, Beena VT, Lal PM, Varghese BJ. Chondro- sarcoma of the maxilla. A D J. 1998; 43: 172-174.

45. Baykul T, Heybeli N, Oyar O, Dogru H. Multiple huge 
osteomas of the mandible causing disfigurement related with Gardner's syndrome: case report. Auris Nasus Larynx. 2003; 30: 447-451.

46. Demirkol M, Ege B, Yanik S, Aras MH, Ay S. Clinicopathological study of jaw cysts in southeast region of Turkey. Eur J Dent 2014;8(1):107-11.

47 Tortorici S, Amodio E, Massenti MF, Buzzanca ML, Burruano F, Vitale F. Prevalence and distribution of odontogenic cysts in Sicily: 1986-2005. J Oral Sci 2008;50(1):158.

48. Ramachandra P, Maligi P, Raghuveer H. A cumulative analysis of odontogenic cysts from major dental institutions of Bangalore city: A study of 252 cases. J Oral MaxillofacPathol 2011; 15(1): 1-5.

49. Koseoglu BG, Atalay B, Erdem MA. Odontogenic cysts: a clinical study of 90 cases. J Oral Sci 2004; 46(4): 253-7.

50. Rezvani G, Pardis S, Sharifi E. A descriptive-clinical study of 134 cases of odontogenic cysts during a 10 year period. Shiraz Univ Dent J 2009; 10(2):122-7.

51. Baghaei F, Zargaran M, Najmi H, Moghimbeigi A. A clinicopathological study of odontogenic cysts and tumors in Hamadan, Iran. J Dent (Shiraz) 2014; 15(4): 167-72.

52. Arotiba JT, Lawoyin JO, Obiechina AE. Pattern of occurrence of odontogenic cysts in Nigerians. East Afr Med J 1998; 75(11): 664-6.

53 Meningaud JP, Oprean N, Pitak-Arnnop P, Bertrand JC. Odontogenic cysts: a clinical study of 695 cases. J Oral Sci 2006; 48(2): 59-62.

54. Fomete B, Osunde OD, Ogbeifun J, Agbara R, Ononiwu CN. A 10-Year Retrospective Analysis of 64 Cases of Cystic Lesions of the Oral and Maxillofacial Region in a Nigerian Tertiary Hospital. Oman Med J 2016; 31(6): 434-438.

55. Açikgöz A, Sakallioglu U, Ozdamar S, Uysal A. Rare benign tumours of oral cavity--capillary haemangioma of palatal mucosa: a case report. Int $\mathrm{J}$ Paediatr Dent. 2000;10:161-5.

56. McHeik JN, Renauld V, Duport G, Vergnes P, Levard G. Surgical treatment of haemangioma in infants. $\mathrm{Br} \mathrm{J}$ Plast Surg. 2005;58:1067-72.

57. Corrêa PH, Nunes LC, Johann AC, Aguiar MC, Gomez RS, Mesquita RA. Prevalence of oral hemangioma, vascular malformation and varix in a Brazilian population. Braz Oral Res. 2007;21:40-5. 